\section{In Vitro Bulb Formation and Plant Recovery from Onion Inflorescences}

Yasseen Mohamed-Yasseen

Tropical Research and Education Center, Institute of Food and Agricultural Sciences, University of Florida, 18905 Southwest 280 Street, Homestead, FL 33031

\section{Walter E. Splittstoesser}

Horticulture Department, University of Illinois, Vegetable Crops Building, 1103 West Dorner Drive, Urbana, IL 61801

\section{Richard E. Litz}

Tropical Research and Education Center, Institute of Food and Agricultural Sciences, University of Florida, 18905 Southwest 280 Street, Homestead, FL 33031

Additional index words. bulb induction, flower head, 'Sweet Spanish' onion, thidiazuron
Where the onion (Allium cepa L.) growing season is long, sets often are planted at the same time as directly seeded crops to produce early onions for market, while prices are high. This method also is useful at high altitudes and latitudes where the growing season is short (Splittstoesser, 1990). One disadvantage of using onion sets is the danger of distributing pests and disease to noninfested land (Jones and Mann, 1963). Producing pest- and disease-free onion sets in vitro would overcome this problem.

'Sweet Spanish' onion plants were grown from seeds (Atlee Burpee Co., Warminster, $\mathrm{Pa}$.) in 1989 under short days and $24 \mathrm{C}$ in a glasshouse. To induce flowering, 7-monthold plants were grown for 5 weeks under 10C, then transferred back to $24 \mathrm{C}$. Immature inflorescences with $5 \mathrm{~mm}$ of scape tissue were surface-disinfested in $70 \%$ ethanol for $1 \mathrm{~min}$ and $0.3 \%$ (by volume) sodium hypochlorite for $10 \mathrm{~min}$ and rinsed three times in sterile, distilled water. Each umbel was quartered longitudinally about the central axis into four explants and placed in vitro. Unless otherwise noted, the medium was composed of Murashige and Skoog (MS) (1962) salts and organics supplemented with $4.4 \mu \mathrm{M} N$ - (phenylmethyl)$1 \mathrm{H}$ - purine-6-amine (BA), $30 \mathrm{~g}$ sucrose, and 8 g agar (Difco Bacto-agar; Fisher, Chicago)/ liter. All explants were placed on $25 \mathrm{ml}$ culture medium contained in 118- or 177-ml babyfood jars and sealed with clear plastic polypropylene lids (Sigma, St. Louis) and Parafilm (Sigma). Medium $\mathrm{pH}$ was adjusted to 5.7 with $1 \mathrm{~N} \mathrm{KOH}$ after adding growth regulators but before adding agar or activated charcoal (AC). All cultures were maintained under an 18-h photoperiod (cool-white fluorescent light, 40 $\left.\mu \mathrm{mol} \cdot \mathrm{m}^{-2} \cdot \mathrm{s}^{-1}\right)$ at $28 \mathrm{C}$.

Received for publication 9 Oct. 1992. Accepted for publication 26 Apr. 1993. Florida Agricultural Experimental Stations journal series no. R-03017. The cost of publishing this paper was defrayed in part by the payment of page charges. Under postal regulations, this paper therefore must he hereby marked advertisement solely to indicate this fact.
Shoot formation in response to $N$ - phenyl$N^{\prime}$ - 1,2,3-thiadiazol-5-ylurea [thidiazuron (TDZ)], a potent cytokinin (Mohamed-Yasseen and Splittstoesser, 1991), was studied. Thus, inflorescence explants were cultured in MS medium supplemented with TDZ at 0.0, 0.005, $0.01,0.05$, or $0.1 \mu \mathrm{M}$.

Regenerated shoots from explants cultured on medium with BA were transferred after 4 weeks to bulb-induction medium composed of MS medium supplemented with $120 \mathrm{~g}$ sucrose and $5 \mathrm{~g} \mathrm{AC/liter} \mathrm{(Mohamed-Yasseen} \mathrm{et} \mathrm{al.,}$ 1993). For direct bulb formation, inflorescence explants were placed directly on the bulb-induction medium indicated above. Bulbs were transferred to soil after 4 to 6 weeks of culturing in the bulb-induction medium, after previous culture on shoot-induction medium, or after 10 to 12 weeks if inflorescence explants were cultured directly in bulb-induction medium. Bulbs from all above treatments were planted in $100-\mathrm{cm}^{2}(10-\mathrm{cm})$ plastic pots filled with autoclave commercial potting soil (Agro Mix no. 2; Conrad Fafard, Springfield, Mass.). The number of established plants was recorded 2 weeks after transfer to soil. Twenty explants were used in each treatment, and each experiment was conducted three times. Data were evaluated by analysis of variance and regression analysis where appropriate.
Multiple shoots [average, $10.6( \pm 1.2 \mathrm{SE})$ after 4 weeks in culture in shoot-induction medium containing BA. Shoot regeneration did not require growth regulators and occurred in MS medium alone. The number of shoots per explant increased when a low concentration of TDZ was added, then decreased with a higher TDZ concentration; this response resulted in a quadratic relationship (Fig. 1). Shoots regenerated in TDZ were yellow, thinner, and shorter than the BA-regenerated shoots (data not shown) and, subsequently, were not transferred to bulb-induction medium.

The number of bulbs per explant from indirect and direct bulb formation was 9.7 and 6.5 , respectively (difference significant at $P \leq$ 0.01 ). Bulbs were transferred to soil without acclimatization. The number of recovered plants per explant from indirect and direct bulb formation was 4.8 and 3.9, respectively (difference significant at $P \leq 0.05$ ). Some regenerated bulbs failed to form plants, possibly because they were small and undeveloped.

In this system, normal, viable plants were obtained from bulbs induced in vitro. This approach to onion propagation, notably direct bulb formation, either obviates or reduces the number of subculture steps required when shoots are regenerated and eliminates the need for shoots to be rooted and elongated. By eliminating certain pathogens, this method has potential to propagate disease-free bulbs rapidly.

\section{Literature Cited}

Jones, H.A. and L.K. Mann. 1963. Onions and their allies-Botany, cultivation and utilization. Leonard Hill, London.

Mohamed-Yasseen, Y., T.L. Davenport, W.E. Splittstoesser, and R.E. Litz. 1993. In vitro shoot proliferation and production of sets from garlic and shallot. Plant Cell, Tissue \& Organ Cult. (In press.)

Mohamed-Yasseen, Y. and W.E. Splittstoesser. 1991. Plant regeneration from stored witloof chicory (Cichorium intybus L.). Plant Growth Regulat. Soc. Amer., Frederick, Md. 19:41-45.

Murashige, T. and F. Skoog. 1962. A revised medium for rapid growth and bioassays with tobacco tissue cultures. Physiol. Plant. 15:473497.

Splittstoesser, E.W. 1990. Vegetable growing handbook. 3rd ed. Van Nostrand Reinhold Co., New York. shoots/explant] were obtained from explants

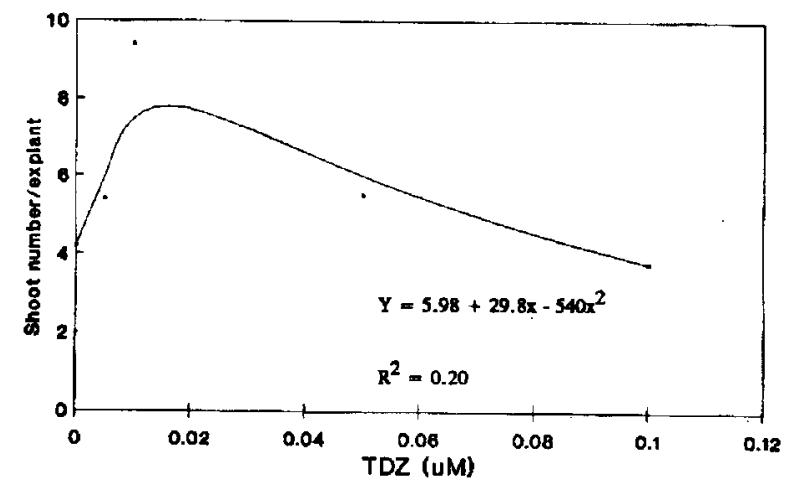

Fig. 1. Effects of TDZ on the number of 'Sweet Spanish' onions produced by inflorescence explants. 